\title{
Extent the Adoption of Organic Farming Practices by Farmers in Crop Production
}

\author{
Shivam Singh ${ }^{1}$, S. K. Singh ${ }^{2}$ and D. V. Singh ${ }^{3 *}$ \\ ${ }^{1}$ Department of Agricultural Extension R.B.S. College, Bichpuri, Agra, India \\ ${ }^{2}$ SMS. Agricultural Extension, Krishi Vigyan Kendra, Awagarh, Etah (U.P.), India \\ ${ }^{3}$ Krishi Vigyan Kendra, Tonk, Rajasthan, India
}

*Corresponding author

\section{A B S T R A C T}

Keywords

Adoption, Organic farming

\section{Article Info}

Accepted:

22 July 2019

Available Online:

10 August 2019

The present study was conducted in Awagarh block of Etah district of Uttar Pradesh to find out the extent of adoption of organic farming practices by farmers in crop production. Study revealed that majority of the farmers 60.00 per cent found to overall medium adoption group followed by low adoption group 22.00 per cent and high adoption of organic farming practices 18.00 per cent respectively. The adoption on different types of organic farming practices, 30.00 per cent farmers had completely adopted the weed control method followed by use of bird pitcher 24.00 per cent, use of neem oil for insect control 23.00 percent, use of recommended bio fertilizer, vermi compost and FYM 21.00 per cent etc. There were 12 components of organic farming practices and the farmers were categorized into three categories (no, partial, complete) as per adoption of particular component.

\section{Introduction}

In India more than 70 per cent of the total population is living in the villages. This population is dependent on agriculture and allied activities for its livelihood. Agriculture is the primary sector of Indian economy. Hence, agriculture has been the back bone of Indian economy. Like India, in Uttar Pradesh farming is also the major source of livelihood and self-employment of near about 80 per cent of the population living in rural areas.
(Badgujjar 2012). It is true that the increasing use of fertilizers and pesticides at high rates has boosted agricultural production in the country. But it has also caused adverse impact on soil and water, as well as environment. Long term continuous use of high doses of chemical fertilizers alone badly affects the soil physical, chemical and biological properties. Rainfall and excess use of irrigation water cause the alkalinity or acidity of the soils. The pesticides and fertilizers mixed with rain or irrigated water and contaminate rivers, wells, 
lakes, etc. and also leak into the drainage system which goes in to the drinking water contaminating the environment. The heavy metals present in the fertilizers, pesticides and sewage sludge leach into ground water. (Kaushik, K.K., 1997).

The global concerns of safe foods have introduced the concept of organic farming. Organic agriculture is an eco-friendly production system that promotes and enhances biodiversity, biological cycles and biological activities. The principle is based on minimal use of off-farm inputs and management practices that help to maintain and enhance ecological balance. Organic agriculture is chemical free. Producing organically is a commitment to a system which ensures that healthy, nutritious food can be produced year after year. The primary goal of organic farming is health and productivity of interdependent communities of soil life, animals and for millions of human beings. (Lukas, M. and Cahn, M., 2008)

"Organic farming is a production system that avoids or largely excludes the use of synthetically compounded fertilizer, pesticides, growth regulators and livestock feed additives. Organic farming systems rely to the maximum extent on crop rotations, crop residues, animal manures, legumes, green manures, off-farm organic wastes, and aspects of biological pest control to maintain soil productivity and tilt, to support plant nutrients and control insects, weeds and other pests". (Kanel, 2005). In Uttar Pradesh, organic farming is being implemented under the guidance of a team of experts consisting of scientists, environmentalists and food management personnel. Nutrients to the crops are provided through green manuring, composts, phospho-composts and fermented preparations prepared from cow dung and urine. Pests are managed through the use of Neem and cow urine based fermented preparations. Eight different ways of composting are recommended in Uttar Pradesh. They are the Indore method, NADEP compost, NADEP phosphor-compost, Vermi compost, Bhabhut amrit pani, Amrit sanjeevani, Pitcher khad, Biogas slurry, Green manures and Bio fertilizer. (Kushwaha, 2003)

\section{Materials and Methods}

The present study was conducted in Awagarh block of Etah district of Uttar Pradesh to find out the extent of adoption of organic farming practices by farmers in crop production. One block namely Awagarh was selected purposively having maximum use of organic farming practices in crops. Hence, the present study has been designed to explore the level of adoption of organic farming practices in Etah district of Uttar Pradesh with specific objective. Similarly a list of farmers adopting organic farming practices of five selected villages was prepared and from the list 100 farmers was selected on the basis of random sampling method. The collected data were tabulated and presented in the form of tables, graphs and other needed form as per the stated objective.

\section{Results and Discussion}

\section{Level of adoption of organic farming practices}

The data presented in table 1 reveals that majority of the farmers 60.00 per cent found to overall medium adoption group followed by low adoption group 22.00 per cent and high adoption of organic farming practices 18.00 per cent respectively.

Thus, it may be concluded that in study area, most of the farmers were found to overall medium adoption of organic farming practices group $(60 \%)$ followed by low and high adoption of organic farming practices. 
Table.1 Distribution of farmers according to their overall extent of level of adoption in respect of organic farming practices

\begin{tabular}{|c|c|c|c|}
\hline S. No. & Categories \& Scores & Frequency & Percentage \\
\hline 1. & Low (1-8) & 22 & 22.00 \\
\hline 2. & Medium (9-16) & 60 & 60.00 \\
\hline 3. & High (17-24) & 18 & 18.00 \\
\hline & Total & 100 & 100.00 \\
\hline
\end{tabular}

Table.2 Distribution of farmers according to their component wise adoption of Organic farming practices

\begin{tabular}{|c|l|c|c|c|}
\hline \multirow{2}{*}{ S. No. } & \multicolumn{1}{|c|}{ Organic farming practices } & \multicolumn{3}{|c|}{ Level of Adoption } \\
\cline { 3 - 4 } & & No & Partial & Complete \\
\hline 1. & Use of summer deep ploughing & 20 & 62 & 18 \\
\hline 2. & Use of crop rotation with pulses for N- fixation & 20 & 61 & 19 \\
\hline 3. & Use of intercropping with pulses for N- fixation & 24 & 60 & 16 \\
\hline 4. & Use of seed treatment & 29 & 61 & 10 \\
\hline 5. & Use of insect resistance variety & 28 & 60 & 12 \\
\hline 6. & Use of recommended bio fertilizer, vermi & 20 & 59 & 21 \\
\hline 7. & Compost and FYM & 29 & 60 & 11 \\
\hline 8. & $\begin{array}{l}\text { Use of trap for insect control } \\
\text { of bird }\end{array}$ & 18 & 58 & 24 \\
\hline 9. & Use of chilli and garlic solution for insect & 30 & 60 & 10 \\
\hline 10. & Use of neem oil for insect control & & & \\
\hline 11. & Use of weed control method & 19 & 58 & 23 \\
\hline 12. & Use of bio insecticide for insect control & 20 & 60 & 20 \\
\hline & Overall average & 22 & 60 & 18 \\
\hline
\end{tabular}

The possible reason for the above findings could be that those practices which were easy to adopt and required less skill were fully adopted by the respondents.

While, those practices which required more knowledge and handling skills were adopted by less number of respondents or the respondents were refused to adopt these components of organic farming practices.

The data in the table 2 reveals that as regard to the adoption on different types of organic farming practices, 30.00 per cent farmers had completely adopted the weed control method followed by use of bird pitcher 24.00 per cent, use of neem oil for insect control 23.00 percent, use of recommended bio fertilizer, vermi compost and FYM 21.00 per cent etc.

There were 12 components of organic farming practices and the farmers were categorized into three categories (no, partial, complete) as per adoption of particular component.

It is evident from the study that the highest level of adoption was found in respect of use 
of weed control method (rank I ${ }^{\text {st }}$ ) followed by use of bird pitcher in the crop field for sitting of bird (rank $\mathrm{II}^{\mathrm{nd}}$ ), use of neem oil for insect control (rank III $^{\text {rd }}$ ), use of recommended bio fertilizer, vermi compost and FYM (rank $\left.\mathrm{IV}^{\mathrm{th}}\right)$, use of bio insecticide for insect control $\left(\right.$ rank $\mathrm{V}^{\text {th }}$ ) respectively.

Higher percentage of the farmers were found to overall medium adoption of organic farming practices group followed by low and high adoption of organic farming practices.

The possible reason for the above findings could be that those practices which were easy to adopt and required less skill were fully adopted by the respondents.

While, those practices which required more knowledge and handling skills were adopted by less number of respondents or the respondents were refused to adopt these components of organic farming practices.

\section{References}

Badgujjar, M.K. (2012). A study on knowledge and adoption of organic farming practices among the farmers in Sehore District (M.P.). M.Sc. (Ag.) Thesis, R.V.S.K.V.V. Gwalior.

Kanel, M.S. (2005). A study on knowledge about organic farming practices possessed by the farmers and their adoption in Dhar district, Madhya Pradesh. M.Sc. (Ag.) Thesis, J.N.K.V.V. Jabalpur.

Khan, Md. Suleman; T. Krishna, and P. Punna. Rao, (2002). Adoption pattern of Eco friendly technology by rice growers. Agril. Extn. Review, March-April, 22-25.
Osari, D. (2011). A Study on Knowledge and Adoption of Organic Farming Practices by Farmers in Indore District of Madhya Pradesh. M.Sc. (Ag.) Thesis, R.V.S.K.V.V. Gwalior.

Ramesh, P. and S. Govind (2001). Adoption of organic farming practices in paddy. Indian J. Extn. Edu., 37(3\&4): 91-94

Ranaganath, A.D.; V. Veerabhadriah, and K.C. Lalitha (2001). Adoption of organic farming practices by small farmers. Agil. Extn. Review. pp: 3-6.

Ravankar, H.N.; R.H. Patil; N.B. Mohod and P.W. Desmukh (2000). Effect of organic farming on yield and soil fertility under cottonsorghum-soybean. P.K.V. Res. J. 24(2): 8083.

Saxena, K.K and R.L. Singh (2000). Adoption of organic farming practices by farmers of Malwa Region. Maharastra Journal of Extn. Edu. 19: 53-55.

Saxena, K.K and T.S. Kushwah (2004). Adoption of organic farming practices. 4(1\&2): 34 .

Sharma, V.K. (1986). A comparative study of the adoption of improved package of practices of Rice and Wheat crop in panagar block. M.Sc. (Ag.) Thesis, J.N.K.V.V. Jabalpur.

Sidram (2008). Analysis of organic farming practices in pigeonpea in Gulbarga district of Karnataka state. M. Sc. (Agri.) Thesis, Univ. Agril. Sci., Dharwad.

Singh, V.K. (2005). A study on behaviour of farmers in relation to organic farming practices in selected block of Rewa district, M.P. M.Sc. (Ag.) Thesis, J.N.K.V.V. Jabalpur.

Sriram, N. and A. Palaniswamy (1999). Farmers' extent of adoption of eco-friendly agriculture practices in cotton cultivation. Journal of Extension Education, 10(1): 2318-2323.

\section{How to cite this article:}

Shivam Singh, S. K. Singh and Singh D. V. 2019. Extent the Adoption of Organic Farming Practices By Farmers in Crop Production. Int.J.Curr.Microbiol.App.Sci. 8(08): 2744-2747. doi: https://doi.org/10.20546/ijcmas.2019.808.316 